\title{
Chemical and behavioral integration of army ant-associated rove beetles - a comparison between specialists and generalists
}

Christoph von Beeren ${ }^{1,2^{*}}$, Adrian Brückner ${ }^{1}$, Munetoshi Maruyama ${ }^{3}$, Griffin Burke ${ }^{2,4}$, Jana Wieschollek ${ }^{1}$ and Daniel J. C. Kronauer ${ }^{2}$

\begin{abstract}
Host-symbiont interactions are embedded in ecological communities and range from unspecific to highly specific relationships. Army ants and their arthropod guests represent a fascinating example of species-rich host-symbiont associations where host specificity ranges across the entire generalist - specialist continuum. In the present study, we compared the behavioral and chemical integration mechanisms of two extremes of the generalist - specialist continuum: generalist ant-predators in the genus Tetradonia (Staphylinidae: Aleocharinae: Athetini), and specialist ant-mimics in the genera Ecitomorpha and Ecitophya (Staphylinidae: Aleocharinae: Ecitocharini). Similar to a previous study of Tetradonia beetles, we combined DNA barcoding with morphological studies to define species boundaries in ant-mimicking beetles. This approach found four ant-mimicking species at our study site at La Selva Biological Station in Costa Rica. Community sampling of Eciton army ant parasites revealed that ant-mimicking beetles were perfect host specialists, each beetle species being associated with a single Eciton species. These specialists were seamlessly integrated into the host colony, while generalists avoided physical contact to host ants in behavioral assays. Analysis of the ants' nestmate recognition cues, i.e. cuticular hydrocarbons (CHCs), showed close similarity in CHC composition and CHC concentration between specialists and Eciton burchellii foreli host ants. On the contrary, the chemical profiles of generalists matched host profiles less well, indicating that high accuracy in chemical host resemblance is only accomplished by socially integrated species. Considering the interplay between behavior, morphology, and cuticular chemistry, specialists but not generalists have cracked the ants' social code with respect to various sensory modalities. Our results support the long-standing idea that the evolution of host-specialization in parasites is a trade-off between the range of potential host species and the level of specialization on any particular host.
\end{abstract}

Keywords: Chemical mimicry, Myrmecophile, Army ant, Host-parasite interaction, Social integration, Cuticular hydrocarbons, DNA barcoding, Eciton burchellii foreli, Ecitophya, Ecitomorpha, Tetradonia

\footnotetext{
* Correspondence: cvonbeeren@gmail.com

${ }^{1}$ Ecological Networks, Department of Biology, Technische Universität

Darmstadt, 64287 Darmstadt, Germany

2Laboratory of Social Evolution and Behavior, The Rockefeller University, New

York, NY 10065, USA

Full list of author information is available at the end of the article
} 


\section{Background}

\begin{abstract}
„Die gelungenste Anpassungstactik ist aber jedenfalls die, dem übermächtigen Gegner als Freund sich anzuschließen und den Grundsatz zu befolgen: ,Mit den Wölfen muss man heulen'. Wem das gelingt, dem ist eben durch die Gesellschaft seiner furchtbarsten Feinde ein mächtiger Schutz und eine reichgedeckte Tafel gesichert." Erich Wasmann (1895)
\end{abstract}

\section{It is the most successful adaptive strategy to join the superior opponent as a friend and to follow the principle: To run with the pack. For those who succeed, the companionship with their most terrifying enemies guarantees powerful protection and richly laden tables.}

In 1894, the Austrian entomologist Erich Wasmann provided a first inventory of ant-associated arthropods, in which he listed more than 1000 species [1]. His seminal work formed the foundation for the study of myrmecophiles (ant lovers) [2-5]. Current estimates of myrmecophile diversity range from 10,000 to 100,000 species $[6,7]$. This species richness is mirrored by a great diversity of life styles spanning from opportunistic ant predators to symbionts that mandatorily depend on the association with ants $[2,8,9]$.

Host-symbiont interactions are embedded in larger ecological networks and range from rather general to highly specific relationships. How these interactions evolve as symbionts become more and more hostspecific is an important question in evolutionary biology in general and parasitology in particular [10]. Host specificity in ant-myrmecophile interactions is known to fall along a generalist - specialist continuum [11]. Even though data about host preferences are scarce (for notable exceptions see e.g. [12-14]), collection records indicate that increasing host specificity is often accompanied by increasing morphological, physiological, and behavioral specialization $[2-4,8,11,13]$.

The aim of the present study was to compare the level of specialization to myrmecophily between ant-associated beetle generalists and beetle specialists. Generalist myrmecophiles with a broad host spectrum often lack conspicuous adaptations to the life with ants and rather resemble free-living relatives $[2-4,7,8]$. For instance, most myrmecophiles of red wood ants occupy a broad host spectrum and are morphologically generalized $[15,16]$. Interestingly, the majority of these myrmecophiles do not mimic the host's chemical recognition cues [17], an otherwise common strategy among myrmecophiles to evade host detection $[18,19]$. In the last years, we systematically assessed the host specificity of army ant myrmecophiles at La Selva Biological Station, Costa Rica [20-23]. Common generalist army ant associates are beetles of the genus Tetradonia (Staphylinidae: Aleocharinae: Athetini) [24], and those are the generalists we studied here. They prey upon ant workers of several host species (range 2-6 host ant species) [20] and show no apparent anatomical modifications compared to free-living staphylinids [25-27]. They are not well integrated into the host colony, where they can usually be found at the periphery, commonly in ant refuse deposits [5, 20, 24].

On the other hand, host specific myrmecophiles often possess conspicuous adaptations to myrmecophily including behavioral, acoustical, anatomical or chemical traits [7, 18, 19, 28-30]. Striking specialist army ant associates are beetles of the tribe Ecitocharini (Staphylinidae: Aleocharinae) [31], and those are the specialists we studied here. Host records indicate that all members of this tribe (10 genera with approximately 20 species [32]) are specifically associated with a single army ant species [11, 25, 27, 32, 33]. These kleptoparasites feed on the prey of host ants while living inside the colonies of army ants [25], in which they are extremely well integrated, behaving as if they were colony members [24, 31]. Most strikingly, some members of this beetle tribe have undergone exceptional anatomical modifications by resembling the body shape and sometimes even the coloration of host ants [25, 27, 32], a type of mimicry termed Wasmannian mimicry [34]. There is no doubt that Wasmannian mimics experienced strong selective pressures to evolve the ant-like habitus, because a myrmecoid body shape has evolved at least 12 times independently within the staphylinid subfamily Aleocharinae [25]. Since army ants have generally poor vision $[31,35,36]$, host resemblance in color likely represents an adaptive response to vertebrate predators such as army antassociated birds [2, 31]. The selective agent driving these beetles towards body shape resemblance is, however, still unknown [25, 31, 32]. Many Wasmannian mimics parasitize army ants with a subterranean life style and differ in body coloration from host ants (see [4]), indicating that visual predators cannot be the only selection pressure acting on Wasmannian mimics. Erich Wasmann himself suggested that tactile inspection of host ants could be responsible for the independent evolution of this ant-like habitus, and called this phenomenon tactile mimicry [37].

In the present study, we compared the behavioral and chemical integration mechanisms of Tetradonia beetles and Wasmannian mimics, representing two extremes of the generalist - specialist continuum, respectively. Similar to a previous study of Tetradonia beetles [20], we combined DNA barcoding with morphological studies to define species boundaries in ant-mimicking beetles, which allowed us, in combination with community sampling of Eciton army ant colonies, to determine 
host specificities in great detail. For one host colony, we compared the behavior of Eciton burchellii foreli (Formicidae: Dorylinae) workers towards specialists and generalists and analyzed the cuticular hydrocarbons ( $\mathrm{CHCs}$ ) of the ants and their guests. CHCs play a central role in ant communication [19, 38-40]. Mimicking those cues is a widespread strategy among myrmecophiles $[18,19$, 28], which has been shown to facilitate their social integration [41]. Finally, we discuss chemical mimicry as an integration strategy and discuss a trade-off between level of specialization and host specificity in army antassociated parasites.

\section{Methods}

\section{Specimen collection and depository}

The study took place in the tropical rainforest at La Selva Biological Station, Costa Rica (N10 25.847' W84 $00.404^{\prime}$, altitude $67 \mathrm{~m}$ asl) in an area of approximately $11 \mathrm{~km}^{2}$ from February to April 2013, March to April 2014, and October 2015. We collected myrmecophiles from colonies of all six local Eciton species during nocturnal army ant emigrations to new bivouac sites using aspirators and forceps. Compared to previous studies [20-23], we analyzed additional colony emigration samples increasing our sample size to 13 colonies of E. burchellii foreli Mayr, 1886 [42], 13 colonies of $E$. hamatum Fabricius, 1781 [43], eight colonies of $E$. vagans angustatum Roger, 1863 [44], 11 colonies of $E$. dulcium crassinode Borgmeier, 1955 [45], 11 colonies of E. mexicanum s. str. Roger, 1863 [44], and two colonies of E. lucanoides conquistador Weber, 1949 [46]. In addition to collections from colony emigrations, we haphazardly collected myrmecophiles from army ant raids and army ant refuse deposits. Collection details are given in Additional file 1: Table S1. This extensive community sampling together with DNA barcoding and morphological identifications of myrmecophiles allowed us to assess host preferences in great detail (see [20,21]).

Samples from a single colony of the swarm-raiding army ant Eciton burchellii foreli (Additional file 1: Table S1) were used to study the chemical and behavioral integration of beetle specialists and beetle generalists. Wasmannian mimics (specialists) were identified to species-level using the identification keys of Kistner \& Jacobson [32] and Reichensperger [47, 48]. Tetradonia beetles (generalists) were identified using the species key of von Beeren et al. [20]. Ants were identified using the identification keys of Watkins [49, 50] and Longino [51]. Army ant workers are vouchered in CvB's personal collection. Wasmannian mimics are deposited at the Kyushu University Museum, Fukuoka, Japan (KUM) as well as in CvB's private collection (see Additional file 2: Table S2). Additionally, 83 voucher images of 21 Wasmannian mimic specimens are deposited in the Barcode of Life database (see Additional file 2: Table
S2). Taxonomy, genetics and host-specificity of Tetradonia beetles have been published previously [20].

\section{Genetic analysis}

Using specimens from our community sampling approach, we determined species boundaries in Wasmannian mimics by analyzing the classical animal barcoding gene cytochrome oxidase I (COI) for 123 specimens collected from 25 colonies, including some specimens collected from army ant raids (Additional file 2: Table S2). DNA extractions and polymerase chain reactions (PCRs) were set up as described previously $[20,21]$. All specimens were preserved during this process and are kept as vouchers (for depository information see Additional file 2: Table S2). The primers LCO1490 and HCO2198 [52] worked reliably, resulting in a 658 base pair (bp) fragment. Purification of PCR products and sequencing was outsourced to Macrogen USA (New York City, USA). All PCR products were sequenced in both directions. All sequences were $658 \mathrm{bp}$ full length reads.

We supplemented the analysis of mitochondrial DNA (mtDNA) with nuclear DNA (nDNA), because mtDNA alone can be problematic for a genetic assessment of species boundaries (e.g., [53]). Hence, we additionally analyzed portions of the nuclear genes wingless ( $\mathrm{Wg}$; sequence lengths ranging from $389 \mathrm{bp}$ to $480 \mathrm{bp}$ ) and $C A D$ (sequence lengths ranging from $483 \mathrm{bp}$ to $653 \mathrm{bp}$ ) for a subset of specimens (Wg: 30 specimens; $C A D$ : 50 specimens; see Additional file 2: Table S2). PCRs were setup as described previously [20-23]. Primer pairs for $W g$ and $C A D$ are given in Additional file 3: Figure S1. For the collection of nuclear sequence data we chose 2-18 specimens of each $C O I$ cluster.

DNA extraction and PCR settings as well as sequencing results were tracked for individual samples using the software Geneious ${ }^{\circ}$ R10 (version 10.2.2) with the plugin 'biocode' (version 3.0.1) [54, 55]. Geneious ${ }^{\circ}$ was also used to trim sequences and to perform Neighbor-Joining (NJ) clustering analysis with bootstrap support (1000 replicates) based on Tamura-Nei distances. NJ trees were used to screen for distinct genetic clusters within the dataset. We rooted NJ trees by using the aleocharine beetle Ecitoglossa sp. (GenBank accession number: MG191453), collected in a Neivamyrmex pilosus emigration at La Selva, as a phylogenetic outgroup (Additional file 2: Table S2). Ecitomorpha cf. nevermanni (KX586175), previously described as Ecitomorpha arachnoides [20], served as outgroup for the NJ tree of Tetradonia beetles. For COI data, we calculated p-distances in pairwise comparisons with pairwise deletion of missing sites using MEGA 6 [56]. All sequences are deposited in GenBank, with accession numbers listed in Additional file 2: Table S2.

\section{Behavioral assays}

Parasites collected from one E. burchellii foreli colony were tested in behavioral assays (Additional file 1: Table 
S1). We studied E. burchellii foreli behavior towards specialists (46 specimens of Wasmannian mimics), generalists (14 specimens of Tetradonia) and 10 heterospecific $E$. hamatum intermediate workers in a laboratory nest setup (plastic box size: $25 \mathrm{~cm}^{*} 15 \mathrm{~cm} * 5 \mathrm{~cm}$ ) with a plaster of Paris floor. The term intermediate refers to middlesized Eciton workers, which were previously also denoted as medias [57] or medium workers [31]. Furrows were scratched into the hardening plaster with a fork to provide hiding spots for parasites. Nest boxes contained approximately 100 E. burchellii foreli workers, including workers of all sizes. A subset of these workers was later used for chemical extractions.

Test animals were introduced one at a time. Each specimen was given a settling time of $30 \mathrm{~s}$, after which we observed its interactions with E. burchellii foreli workers for one minute. We counted the number of contacts of test specimens with E. burchellii foreli workers. A contact was defined as physical contact between any body part of the focal test animal and an $E$. burchellii foreli worker. This included short-lasting interactions such as antennal touch as well as long-lasting contacts such as reciprocal grooming (see [58] for possible ant-myrmecophile interactions). Lasting contacts with the same individual ant were only counted once. In addition, we counted the number of aggressive ant behaviors (chasing, snapping, stinging attempt) towards test specimens. Aggressive ant behaviors were defined previously $[41,59]$.

Behavioral assays were analyzed in R 3.3.1 [60]. The number of contacts and the number of aggressive behaviors of E. burchellii foreli workers towards E. hamatum intermediates, Wasmannian mimics (specialists) and Tetradonia beetles (generalists) were compared using Kruskal-Wallis tests [61]. We did not find differences in contact frequency with host ants between different species of Wasmannian mimics (Kruskal-Wallis test, $\mathrm{X}^{2}=3.16, \mathrm{df}=2, P=0.205$; Fig. 1a) or between different Tetradonia species (Kruskal-Wallis test, $\chi^{2}=$ $2.15, \mathrm{df}=1, P=0.131$; Fig. 1a). Specimens of the different species were therefore pooled into the categories specialists and generalists, respectively. The same applies for the analysis of ant aggression (Fig. 1b). As post-hoc analyses we used Dunn's multiple comparisons rank sum test [62] with false discovery rate correction to account for type I error-accumulation [63] as implemented in the R package PMCMR [64].

\section{Chemical analysis}

The same individuals studied in behavioral assays were chemically analyzed. Chemical extractions of specimens took place within a period of 1-15 min after the behavioral test. We extracted the cuticular hydrocarbons (CHCs) of ant specimens (10 minor, 9 intermediate, 10 major workers, and 10 larvae of E. burchellii foreli, and 11 intermediate workers of $E$. hamatum), 45 Wasmannian mimics (specialists), and 14 Tetradonia beetles (generalists). Eciton hamatum, an heterospecific, congeneric army ant species, was used as a chemical outgroup. Each specimen was submersed in $200 \mu \mathrm{ln}$-hexane (98\% purity for gas-chromatography) at room temperature for $10 \mathrm{~min}$. Subsequently, the animals were removed from the solvent and preserved in alcohol for genetic and morphological analyses. The hexane was then evaporated at room temperature in a fume-hood.

The $\mathrm{CHC}$ residuals were re-dissolved in $40 \mu \mathrm{l}$ hexane containing hexadecane as internal standard. The concentrations of our internal standard were adjusted
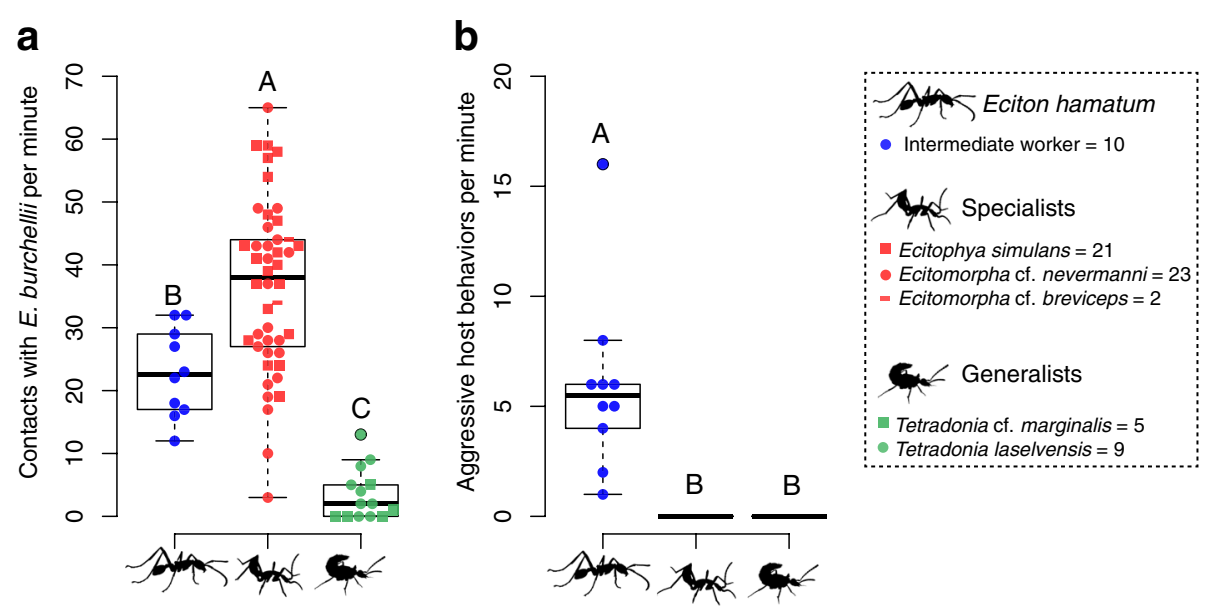

Fig. 1 Behavioral assays. a The number of contacts between Eciton burchellii foreli workers with test specimens and $\mathbf{b}$ the number of aggressive host behaviors towards test specimens. No aggressive host behavior was detected against Wasmannian mimics (specialists) and Tetradonia beetles (generalists), and individual data points are therefore not plotted. Different letters depict significant differences ( $p<0.05)$ as assessed by a Dunn's test 
according to body size. We used 5 ng hexadecane / $1 \mu \mathrm{l}$ hexane for Wasmannian mimics, Tetradonia beetles, and all ants except for E. burchellii foreli majors, for which we used $15 \mathrm{ng} / \mu \mathrm{l}$. Then, $20 \mu \mathrm{l}$ of the samples were transferred into conical glass inlets. We analyzed the samples with a QP 2010ultra GC-MS (Shimadzu, Japan). The gas chromatograph was equipped with a ZB-5MS fused silica capillary column $(30 \mathrm{~m} \times 0.25 \mathrm{~mm} \mathrm{ID}, \mathrm{df}=$ $0.25 \mu \mathrm{m})$ from Phenomenex (USA). An AOC-20i autosampler-system from Shimadzu was used to inject $1 \mu \mathrm{l}$ sample aliquot into a programmed temperature vaporizing split/splitless-injector (Optic MultiMode Inlet 4, GL Sciences, Netherlands), which operated in splitless-mode. Injection temperature was programmed from initially $50{ }^{\circ} \mathrm{C}$ ( 5 s hold) to $300{ }^{\circ} \mathrm{C}$ with a heatingrate of $50{ }^{\circ} \mathrm{C} / \mathrm{s}$ and a subsequent hold for $59 \mathrm{~min}$. Hydrogen was used as carrier-gas with a constant flow rate of $1.3 \mathrm{ml} / \mathrm{min}$. The temperature of the GC oven was raised from an initial $60{ }^{\circ} \mathrm{C}$ for $1 \mathrm{~min}$, to $320^{\circ} \mathrm{C}$ with a heating-rate of $5.5^{\circ} \mathrm{C} / \mathrm{min}$ and then an isothermal hold at $320{ }^{\circ} \mathrm{C}$ for $10 \mathrm{~min}$. Electron ionization mass spectra were recorded at $70 \mathrm{eV}$ with a scan rate of 2 scans per sec from $\mathrm{m} / \mathrm{z} 40$ to 650 . The ion source of the mass spectrometer and the transfer line were kept at $230{ }^{\circ} \mathrm{C}$ and $300{ }^{\circ} \mathrm{C}$, respectively.

Pooled extracts of 10 ant workers were used for compound identification. The CHCs were identified based on their $\mathrm{m} / \mathrm{z}$ fragmentation patterns and gas chromatographic retention indices (RI), which were calculated using an alkane standard mixture (C7-C40 dissolved in hexane; Sigma-Aldrich, Germany) using the method of van den Dool \& Kratz [65]. The structural identities of methylbranched alkanes were assigned according to established procedures [66, 67]. The double bond positions in alkenes and alkadienes were identified using iodine-catalyzed dimethyldisulfide derivatization [68]. The configurations of double bonds were not determined.

$\mathrm{CHCs}$ of ants and myrmecophiles were analyzed as compositional data (i.e. percentages of $\mathrm{CHCs}$ per specimen). For each specimen, $\mathrm{CHCs}$ below a threshold of $5 \%$ of the total $\mathrm{CHC}$ amount were not considered to account for a potential bias caused by assaying animals of vastly different body sizes. The $\mathrm{CHC}$ compositional data were analyzed using discriminant analysis of principal components (DAPC). DAPC is a powerful method to discriminate a priori assigned groups in a multivariate ordination of chemical compositional data [69]. It transforms the original compositional data by PCA prior to the discriminant analysis (DA) and therefore values become uncorrelated [70]. We retained three PC-axes based on their Eigenvalues and the explained variance. We further used PERMANOVA [71] based on 10,000 permutations with Bray-Curtis similarities [72] to test for compositional differences of $\mathrm{CHC}$ profiles among groups and PERMDISP $[69,71]$ to test the compositional stability of $\mathrm{CHC}$ profiles among ants, beetle specialists, and beetle generalists. Permutational analysis of variance (PERMANOVA) and permutational analysis of multivariate dispersions (PERMDISP) were run with the $R$ packages adegenet [73] and vegan [74], respectively. PERMANOVA pair-wise tests and PERMDISP pair-wise tests were run with the software Primer 7 (Primer-E Ltd., Ivybridge, U.K., vers. 7.0.12) with the add-on PERMANOVA+ 1 [75]. We did detect differences in $\mathrm{CHC}$ composition among species of Wasmannian mimics (PERMANOVA, Pseudo-F $=9.545, \quad P<$ 0.001; PERMDISP, $\mathrm{F}=1.357, P=0.829)$ and between Tetradonia species (PERMANOVA, Pseudo-F $=3.941, P$ $<0.012$; PERMDISP, $\mathrm{F}=0.194, P=0.389$ ). However, we still pooled the different species into the respective categories being aware that minor differences existed among species within groups, because the aim of the present study was to compare two distinct groups of ant parasites: beetle specialists and beetle generalists.

The amounts of $\mathrm{CHCs}$ [in ng] were calculated based on the internal standard hexadecane as described in [76]. To consider differences in body size among specimens we either standardized using the body mass [in mg dry weight; see Additional file 3: Figure S2 for all dry weight measurements] or the estimated surface area with the obtained dry weight data $\left[\right.$ in $\mathrm{mg}^{2 / 3}$ ] (see [77]). The latter analysis accounts for the faster increase of volume compared to surface area (in this study the dry weight) when a size of an object increases (square-cube law; [78]). The frequent exchange of $\mathrm{CHCs}$ among ant nestmates creates a uniform colony odor, the so-called gestalt odor [19, 79]. Owing to the gestalt odor, we expected to find a positive relationship between $\mathrm{CHC}$ amount and body size in ants. Indeed, we found a linear relationship between body mass and $\mathrm{CHC}$ amount of E. burchellii foreli workers including specimens from different castes $(N=28$, F-value: $113, P<0.001$; Additional file 3 : Figure S3). This indicated that the dry weight is a good predictor for an animal's surface area and thus can be used to assess the $\mathrm{CHC}$ concentration, assuming a relatively constant shape of the study object. To obtain the body mass, we dried the specimens until weight constancy for at least $48 \mathrm{~h}$ at $45{ }^{\circ} \mathrm{C}$ and determined their dry weight using a microbalance (Mettler Toledo, XS3DU, USA). The CHCs per dry weight $[\mathrm{ng} / \mathrm{mg}]$ or per estimated surface area [ng/ body $\mathrm{mass}^{2 / 3}$ ] were analyzed using Kruskal-Wallis tests and affiliated Dunn's tests as described above. No differences were found among species of Wasmannian mimics (ng/mg: Kruskal-Wallis test, $x^{2}=4.367, \mathrm{df}=2$, $P=0.113 ; \mathrm{ng} / \mathrm{mg}^{2 / 3}:$ Kruskal-Wallis test, $x^{2}=3.416, \mathrm{df}$ $=2, P=0.181)$ or between Tetradonia species $(\mathrm{ng} / \mathrm{mg}$ : 
Kruskal-Wallis test, $\chi^{2}=0.751, \mathrm{df}=1, P=0.386 ; \mathrm{ng} / \mathrm{mg}^{2 / 3}$ : Kruskal-Wallis test, $\chi^{2}=0.111, \mathrm{df}=1, P=0.739$ ). Specimens of the different species were pooled into the categories specialists and generalists, respectively.

\section{Results}

\section{Genetic assessment of species boundaries}

Genetic assessment of species boundaries revealed the presence of four candidate species of Wasmannian mimics (specialists) and five candidate species of Tetradonia beetles (generalists) in the Eciton-myrmecophile community at La Selva (Fig. 2a; for detailed results about Tetradonia beetles see [20]). The NJ-tree clustering analysis revealed four distinct genetic clusters in Wasmannian mimics (Fig. 2a). The four $C O I$ clusters were also recovered with the nuclear loci $W g$ and $C A D$ (Additional file 3: Figure S1). There was no haplotype overlap between $C O I$ clusters (within clusters: $E$. cf. breviceps: 4 haplotypes, $N=10$ specimens sequenced; $E$. cf. nevermanni: 12 haplotypes, $N=36$ specimens sequenced; E. gracillima: 5 haplotypes, $N=20$ specimens sequenced; $E$. simulans: 16 haplotypes, $N=57$ specimens sequenced). Similarly, there was no sequence overlap between genetic clusters in $C A D$ or in $W g$ (number of $C A D / W g$ sequences: $E$. cf. breviceps $=2 / 3$; E. $\quad$ cf. nevermanni $=14 / 15 ; \quad E$. gracillima $=18 / 2 ; \quad E$. simulans $=16 / 9)$. The distribution of intraspecific- and interspecific genetic $\mathrm{p}$-distances in pairwise comparisons of COI sequences revealed a gap between maximum intraspecific- and minimum interspecific genetic distances of mitochondrial sequences (Additional file 3: Figure S4). Such 'barcoding gaps' provide additional support for the presence of distinct species (but see [53]).

\section{Taxonomy and host specificity}

Guided by the molecular work, we were able to reliably distinguish the four candidate species of beetle specialists on the basis of several anatomical characters. We identified them as the following species: Ecitophya simulans Wasmann 1889, Ecitophya gracillima Mann 1925, Ecitomorpha cf. nevermanni Reichensperger 1935 and Ecitomorpha cf. breviceps Reichensperger 1933.

Ecitophya simulans and E. gracillima are similar to each other externally, but they are clearly distinguished in the head capsule and antennal shapes. In E. simulans the head length is less than twice as long as wide (head length/ head width =1.91-1.93), and the antennal segment II is about half as long as the segment X, while in E. gracillima the head length is more than twice as long as wide (head length/ head width $=2.26-2.30$ ), and the segment II is less than $1 / 3$ of the segment X. The two species can also be distinguished by their color. The
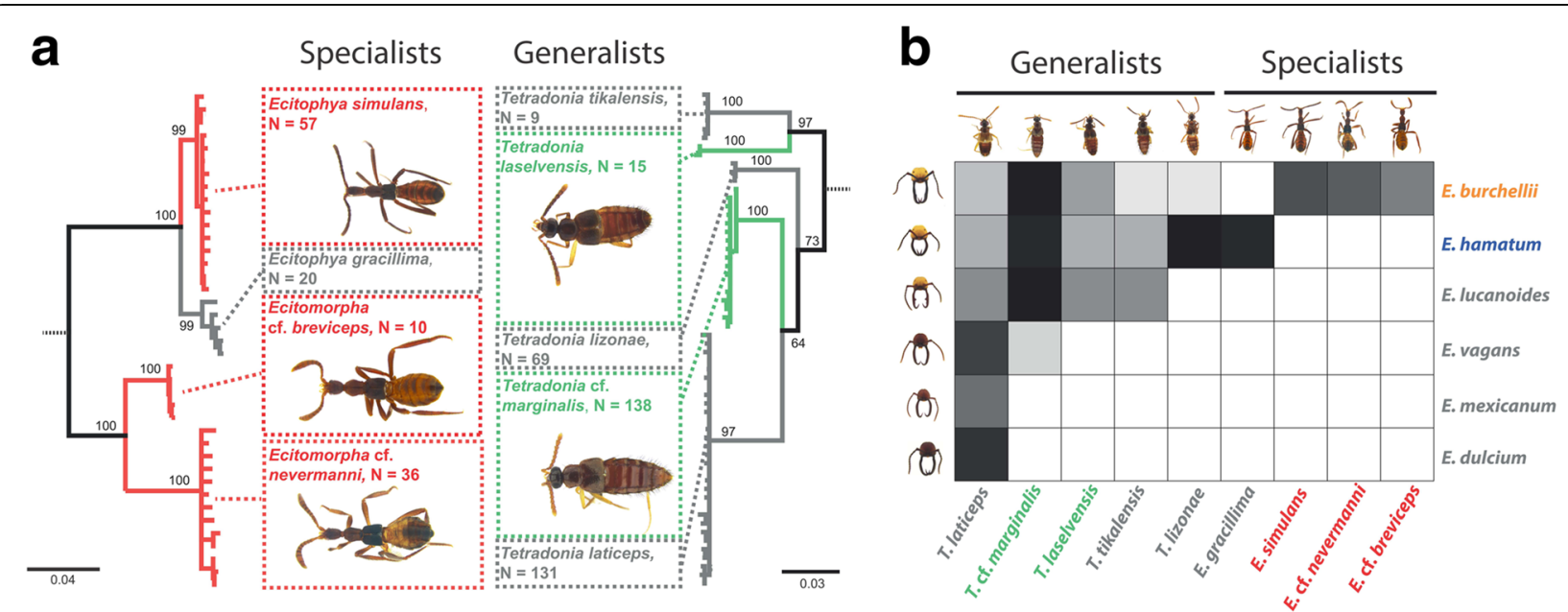

Fig. 2 Genetic assessment of parasite species boundaries and parasite host preferences. Coloration depicts species that were also studied in behavioral and chemical analysis (red=specialists; green = generalists; orange = E. burchellii foreli; blue = E. hamatum; see also other figures). Grey boxes depict species that were not considered further. a Neighbor-joining trees based on Tamura-Nei distances (scale bars) of the mitochondrial gene fragment COI detected four genetic clusters for Ecitophya and Ecitomorpha (specialists) and five genetic clusters for Tetradonia (generalists). We excluded the genetic outgroups from the NJ trees for better visibility (indicated by dashed lines; outgroups: Ecitoglossa sp. for specialists and Ecitomorpha cf. nevermanni for generalists). Numbers of analyzed specimens is given in boxes. Bootstrap support values are shown at major branches (1000 replicates). $\mathbf{b}$ Host specificity of Tetradonia beetles (generalists) and Wasmannian mimics (specialists). Differential shading corresponds to the proportion of colonies of a given host species in which a given parasite species was collected. White boxes depict missing associations between parasites and army ants. Black boxes show myrmecophiles that were collected in all colonies of a given host species. Photographs depict frontal head views of Eciton soldier workers and dorsal views of beetles for the different species. Data on Tetradonia species boundaries and host specificity have been published previously [20]. Specimen images are not to scale in both graphs 
abdominal tergite VI of Ecitophya simulans is almost uniformly reddish brown, but that of E. gracillima is clearly dark with brownish tinge around middle area. The two Ecitomorpha species are easily distinguishable by the shape of the pronotal incision, the absolute and relative length of antennal segments, and the shape of the head (for details see Additional file 3: Figure S5). Note that Ecitomorpha formally contains a single species (i.e. E. arachnoides Wasmann 1889) [32]. In the latest revision of Ecitocharini, Kistner \& Jacobson synonymized the species E. arachnoides, E. melanotica Mann 1926, E. breviceps Reichensperger 1933, and E. nevermanni Reichensperger 1935 [32]. However, our genetic and morphological analyses revealed the presence of two distinct Ecitomorpha species, which matched well to the species descriptions of E. breviceps and E. nevermanni (Additional file 3: Figure S5). We therefore decided to refer to the species studied here as Ecitomorpha cf. nevermanni and Ecitomorpha cf. breviceps (cf. = confer).

Each species of Wasmannian mimic was specifically associated with a single host (Fig. 2b). Ecitophya gracillima was exclusively associated with $E$. hamatum (Fig. $2 b$ ). It was found in 12 out of $13 \mathrm{E}$. hamatum colonies from which myrmecophiles were collected systematically. Ecitophya simulans, Ecitomorpha cf. breviceps, and Ecitomorpha cf. nevermanni were exclusively collected from E. burchellii foreli colonies and were present in 11, 7, and 9 out of 13 systematically sampled colonies, respectively. Wasmannian mimics were not found with any of the other Eciton species occurring at La Selva (E. dulcium, $N=11$ sampled colonies; $E$. lucanoides, $N=2 ; E$. mexicanum, $N=11 ; E$. vagans, $N=8$ ). Note that another Wasmannian mimic, the beetle Ecitophya rettenmeyeri Kistner \& Jacobson 1990, was previously collected at La Selva from E. lucanoides but was not detected in the current samples. Figure $2 \mathrm{~b}$ also reviews species boundaries and host specificity of Tetradonia beetles. These data have been published previously [20].

\section{Behavioral assays}

We observed that Wasmannian mimics actively sought contact with host ants and often engaged in reciprocal grooming behavior with workers (see Additional file 4). In contrast, Tetradonia beetles avoided host contact and mostly hid in gypsum cavities. Congeneric E. hamatum workers also avoided contact but were regularly seized by E. burchellii foreli workers. Accordingly, we found differences among groups in host contact frequency (Kruskal-Wallis test, $\chi^{2}=37.84, \mathrm{df}=2, P<0.001$; Fig. 1a). Wasmannian mimics (specialists) and E. hamatum workers interacted more often with $E$. burchellii foreli workers in behavioral assays than Tetradonia beetles (generalists) (mean number of contacts per minute \pm
SD; E. hamatum: $23 \pm 7, N=10$; specialists: $37 \pm 14$, $N=46$; generalists: $3.5 \pm 4, N=14$; Fig. 1a).

Host aggression against test specimens also differed among groups (Kruskal-Wallis test, $\mathrm{X}^{2}=68.47 \mathrm{df}=2, P$ $<0.001$; Fig. 1b). Congeneric E. hamatum workers $(N=$ 10 ) were aggressed by $E$. burchellii foreli workers (mean \pm SD: $6 \pm 4$ aggressive events per minute), while we detected no aggression towards Wasmannian mimics and Tetradonia beetles (Fig. 1b). During field and additional laboratory observations, however, we did occasionally observe aggression towards Tetradonia beetles, but not towards Wasmannian mimics.

\section{Chemical profiles of hosts and myrmecophiles}

Workers of Eciton burchellii foreli and Eciton hamatum army ants possessed simple cuticular chemical profiles dominated by three main compounds (Table 1): heneicosane (C21), tricosane (C23) and 9-tricosene (C23-9-ene). Similar CHCs were found in Wasmannian mimics (specialists) and Tetradonia beetles (generalists) (Table 1). No additional, myrmecophile-specific $\mathrm{CHCs}$ were detected (Table 1).

$\mathrm{CHC}$ composition differed among the following groups: 'specialist', 'generalist', 'E. hamatum', 'E. burchellii major', 'E. burchellii intermediate', 'E. burchellii minor', and 'E. burchellii larva' (PERMANOVA, Pseudo-F $=43.13, P<$ 0.001). In PERMANOVA pairwise comparisons all groups differed from each other (PERMANOVA, $P \leq 0.031$ ) except for Wasmannian mimics (specialists) and E. burchellii larvae (PERMANOVA, $P=0.141$ ). We also detected differences in the within-group variance (PERMDISP, $\mathrm{F}=$ 4.449, $P=0.003$ ) with $\mathrm{CHC}$ compositional data being more dispersed in Tetradonia beetles than in ants and Wasmannian mimics (Fig. 3).

The DAPC ordination provided strong evidence that chemical profiles of host ants were qualitatively very similar to the profiles of specialists (Fig. 4). Apart from one minor worker, a DAPC reassignment of a priori defined groups could not distinguish $\mathrm{CHC}$ profiles of larvae, minor workers and intermediate workers of E. burchellii foreli from $\mathrm{CHC}$ profiles of 'specialists' (Additional file 3: Table S3). In contrast, E. burchellii foreli major workers and Tetradonia beetles (generalists) had distinct chemical profiles (Fig. 4) and were robustly assigned to their respective group by the DAPC (Additional file 3: Table S3).

The CHC concentration also differed among the groups (for ng/mg: Kruskal-Wallis test, $x^{2}=19.66, \mathrm{df}=2$, $P<0.001$, Fig. $5 \mathrm{a}$; for $\mathrm{ng} / \mathrm{mg}^{2 / 3}$ : Kruskal-Wallis test, $\mathrm{X}^{2}=$ 35.62, $\mathrm{df}=2, P<0.001$, Fig. 5b). Depending on the method used for body size correction, the $\mathrm{CHC}$ concentration of ant workers and beetle specialists either did not differ when standardizing the $\mathrm{CHC}$ amount for dry weight (Dunn's post hoc test, $P=0.620$; Fig. 5a) or it differed for the estimated surface area in that beetle 
Table 1 Relative abundances of CHC compounds

\begin{tabular}{|c|c|c|c|c|c|c|c|c|c|c|c|}
\hline \multirow[t]{2}{*}{ CHC identification } & \multirow[t]{2}{*}{$\mathrm{Rl}$} & \multicolumn{2}{|l|}{ Generalists } & \multicolumn{3}{|l|}{ Specialists } & \multicolumn{4}{|c|}{ Eciton burchellii foreli } & \multirow{2}{*}{$\begin{array}{l}\text { Eciton hamatum } \\
\text { intermediate }\end{array}$} \\
\hline & & $\begin{array}{l}\text { Tetradonia } \\
\text { laselvensis }\end{array}$ & $\begin{array}{l}\text { Tetradonia of. } \\
\text { marginalis }\end{array}$ & $\begin{array}{l}\text { Ecitomorpha cf. } \\
\text { breviceps }\end{array}$ & $\begin{array}{l}\text { Ecitomorpha cf. } \\
\text { nevermanni }\end{array}$ & $\begin{array}{l}\text { Ecitophya } \\
\text { simulans }\end{array}$ & larva & minor & $\begin{array}{l}\text { inter- } \\
\text { mediate }\end{array}$ & major & \\
\hline C21-6,9-diene & 2069 & - & - & - & - & - & - & - & - & - & 0.02 \\
\hline C21-9-ene & 2075 & - & - & 0.95 & 0.82 & 0.86 & - & 1.27 & 1.39 & 0.92 & 0.99 \\
\hline c21-7-ene & 2080 & - & - & - & 0.11 & - & - & 0.04 & - & 0.04 & 0.05 \\
\hline $\mathrm{C} 21$ & 2100 & 21.73 & 17.48 & 22.33 & 20.72 & 16.43 & 17.43 & 19.29 & 16.34 & 8.04 & 15.24 \\
\hline 11-Me-C21 & 2138 & - & - & - & - & - & - & - & - & 0.03 & 0.13 \\
\hline 9-Me-C21 & 2142 & - & - & - & - & - & - & - & - & - & 0.01 \\
\hline c22-9-ene & 2174 & - & - & - & 0.08 & 0.60 & - & 0.10 & 0.11 & 0.18 & 0.15 \\
\hline C22-7-ene & 2181 & - & - & - & - & 0.18 & - & - & - & - & 0.01 \\
\hline $\mathrm{C} 22$ & 2200 & 2.32 & 1.07 & 1.37 & 1.31 & 1.01 & 0.29 & 1.26 & 0.71 & 0.19 & 0.32 \\
\hline C23-6,9-diene & 2271 & - & - & 0.46 & 0.77 & 0.93 & 0.56 & - & 0.49 & 0.77 & 0.19 \\
\hline c23-9-ene & 2286 & 24.06 & 32.83 & 38.09 & 46.60 & 54.74 & 57.33 & 44.82 & 58.23 & 80.33 & 75.19 \\
\hline C23-7-ene & 2289 & 0.96 & 5.07 & 2.20 & 2.26 & 2.40 & 1.30 & 2.02 & 1.04 & 1.00 & 0.15 \\
\hline C23:1 & 2295 & 0.28 & 0.35 & 0.69 & 0.37 & 0.38 & 0.00 & 0.23 & 0.22 & 0.21 & 0.02 \\
\hline $\mathrm{C} 23$ & 2300 & 38.81 & 35.85 & 26.25 & 21.98 & 16.73 & 19.21 & 22.82 & 15.79 & 6.04 & 6.42 \\
\hline Me-C23 & 2324 & - & - & - & - & - & - & - & - & 0.07 & - \\
\hline 11-Me-C23 & 2335 & 0.55 & 1.03 & 0.95 & 0.52 & 0.61 & 0.16 & 0.89 & 0.49 & 0.22 & 0.05 \\
\hline 9-Me-C23 & 2341 & 0.20 & 0.21 & - & 0.04 & 0.10 & - & 0.33 & 0.23 & 0.05 & 0.01 \\
\hline $\mathrm{C} 24$ & 2400 & 0.49 & - & - & 0.09 & 0.12 & - & 0.37 & 0.21 & 0.04 & 0.01 \\
\hline C25-6,9-diene & 2469 & - & - & - & - & - & - & - & - & 0.01 & 0.00 \\
\hline C25-9-ene & 2475 & 0.20 & 0.99 & 1.31 & 0.87 & 1.54 & 0.18 & 0.94 & 0.88 & 0.73 & 0.14 \\
\hline c25-7-ene & 2484 & - & - & 0.18 & 0.31 & 0.32 & - & 0.15 & 0.22 & 0.18 & 0.01 \\
\hline $\mathrm{C} 25$ & 2500 & 10.38 & 5.11 & 5.21 & 3.12 & 2.79 & 3.55 & 4.62 & 2.72 & 0.63 & 0.32 \\
\hline 11-Me-C25 & 2535 & - & - & - & - & - & - & - & - & 0.03 & - \\
\hline $\mathrm{C} 26$ & 2600 & - & - & - & - & - & - & - & - & 0.01 & - \\
\hline C27-9-ene & 2675 & - & - & - & - & - & - & - & 0.02 & 0.01 & - \\
\hline C27-7-ene & 2684 & - & - & - & - & - & - & - & - & 0.01 & - \\
\hline $\mathrm{C} 27$ & 2700 & - & - & - & 0.03 & 0.21 & - & 0.78 & 0.57 & 0.12 & 0.21 \\
\hline 11-Me-C27 & 2772 & - & - & - & - & - & - & - & - & $\operatorname{tr}$ & - \\
\hline C29-6,9-diene & 2870 & - & - & - & - & - & - & - & - & $\operatorname{tr}$ & - \\
\hline c29-9-ene & 2875 & - & - & - & - & - & - & - & - & $\operatorname{tr}$ & - \\
\hline c29-7-ene & 2886 & - & - & - & - & - & - & - & - & $\operatorname{tr}$ & - \\
\hline C29 & 2900 & - & - & - & - & 0.04 & - & - & 0.20 & 0.06 & 0.17 \\
\hline C30:1 & 2985 & - & - & - & - & - & - & 0.07 & - & 0.02 & - \\
\hline C31:1 & 3050 & - & - & - & - & - & - & - & - & 0.01 & 0.11 \\
\hline C31:1 & 3076 & - & - & - & - & - & - & - & - & - & 0.02 \\
\hline C31 & 3100 & - & - & - & - & - & - & - & 0.11 & 0.03 & 0.06 \\
\hline Me-C31 & 3145 & - & - & - & - & - & - & - & - & 0.01 & - \\
\hline
\end{tabular}

Relative abundances of individual components to the specimen's total peak area are given for different Eciton burchellii foreli castes, different parasite species, and Eciton hamatum intermediate workers. Values represent means of each category (for sample sizes for each category see Results). Abbreviations: $R /$ retention index, tr traces detected, - not detected

specialists had lower $\mathrm{CHC}$ concentrations than ants (Dunn's post hoc test, $P=0.002$; Fig. 5b). Beetle generalists showed lower $\mathrm{CHC}$ concentrations than workers and beetle specialists, irrespective of the method used for body size correction (Dunn's post hoc test for both analyses, $P<0.001$; Fig. 5a,b). 


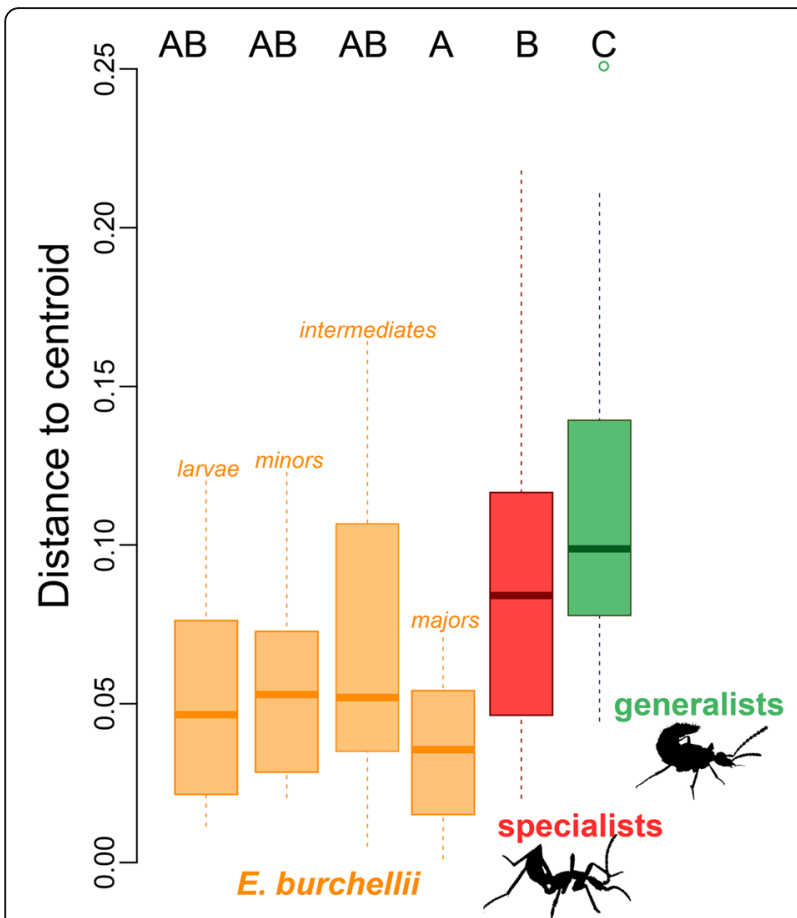

Fig. 3 Dispersion of $\mathrm{CHC}$ profiles within categories. Distance to centroid in $\mathrm{CHC}$ compositional data (based on Bray-Curtis similarities) for the categories larvae $(N=8)$, minor workers $(N=10)$, intermediate workers $(N=9)$, major workers $(N=10)$, Wasmannian mimics (specialists; $N=44$ ) and Tetradonia beetles (generalists; $N=14$ ). Capital letters depict significant differences in permutational pairwise comparisons (PERMDISP pairwise test; $P<0.05$ )

\section{Discussion}

Community sampling of army ant myrmecophiles, combined with an integrated study of beetle taxonomy, unveiled the presence of four Eciton-associated species of Wasmannian mimics at La Selva, Costa Rica. Each of these specialized mimics was specifically associated with a single host species. We compared the chemical and behavioral integration of these specialists with a group of beetle generalists, i.e. Tetradonia beetles. We found that specialists showed a higher level of social integration and a closer match to host $\mathrm{CHC}$ profiles.

\section{Assessing species boundaries}

Communities of army ant myrmecophiles are speciesrich $[5,31]$. To efficiently determine myrmecophile species boundaries, we applied a molecular pre-screening mechanism using classical DNA barcoding of the mitochondrial locus $\mathrm{COI}$ combined with the analysis of two nuclear loci [20-23]. Distinct COI clusters that were also recovered with nuclear loci were considered to represent candidate species (see also [53]), which were subsequently inspected morphologically. This approach already helped us distinguish species in other army ant associates [22, 23], including taxonomically difficult groups such as Vatesus (Staphylinidae: Tachyporinae) and Tetradonia beetles [20,21].

In the present study, we determined species boundaries in Eciton-associated Ecitophya and Ecitomorpha beetles. Genetic and morphological inspection agreed on the presence of four distinct species in the La Selva community. Two of these species were members of the genus Ecitomorpha, which formally contains only a single species (see latest revision [32]). It seems likely that these two species had been previously described as Ecitomorpha nevermanni [47] and Ecitomorpha breviceps [80] and were later mistakenly synonymized by Kistner \& Jacobson [32]. However, a validation of these tentative species identifications, including careful morphological inspection of type material, is necessary.

A recent genetic study [33] likewise indicated cryptic diversity in Ecitophya and Ecitomorpha. The study revealed strong intrageneric genetic divergence in beetles associated with two distinct host subspecies, Eciton burchellii parvispinum and Eciton burchellii foreli, which were studied in West and Central Panama, respectively. However, given the lack of morphological data in that study, it remains to be determined whether the detected genetic differences are in fact continuous and derive from limited gene flow due to the geographic distance separating the two study areas, or whether the two populations indeed represent reproductively isolated populations and, therefore, different species (see also discussion in [22]). Either way, these results and the data presented here certainly call for a careful taxonomic revision of this fascinating group of army ant-associated rove beetles, which would ideally include samples covering the beetles' distributional range to more reliably assess species boundaries (see [33] and discussion in [22]).

\section{Host specificity of Wasmannian mimics}

The level of host specificity plays a fundamental role in symbiotic interactions $[10,11,81,82]$. However, its assessment can be challenging $[10,11]$. It requires sampling of a community of possible host species and a correct delimitation of species boundaries [10, 13, 21]. Previous host records of Wasmannian mimics, however, were either based on haphazard collections from different populations, or considered only a fraction of potential host species in a given community [27, 32, 33, 83]. Even though they suggested an association with a single host species, this conclusion remained questionable [27, 32, 83]. Combining our extensive collection of myrmecophiles from large numbers of Eciton colonies within a single community with the genetic and morphological assessment of species boundaries allowed us to reliably determine host specificities, confirming a single host association in four species of Wasmannian mimics. 


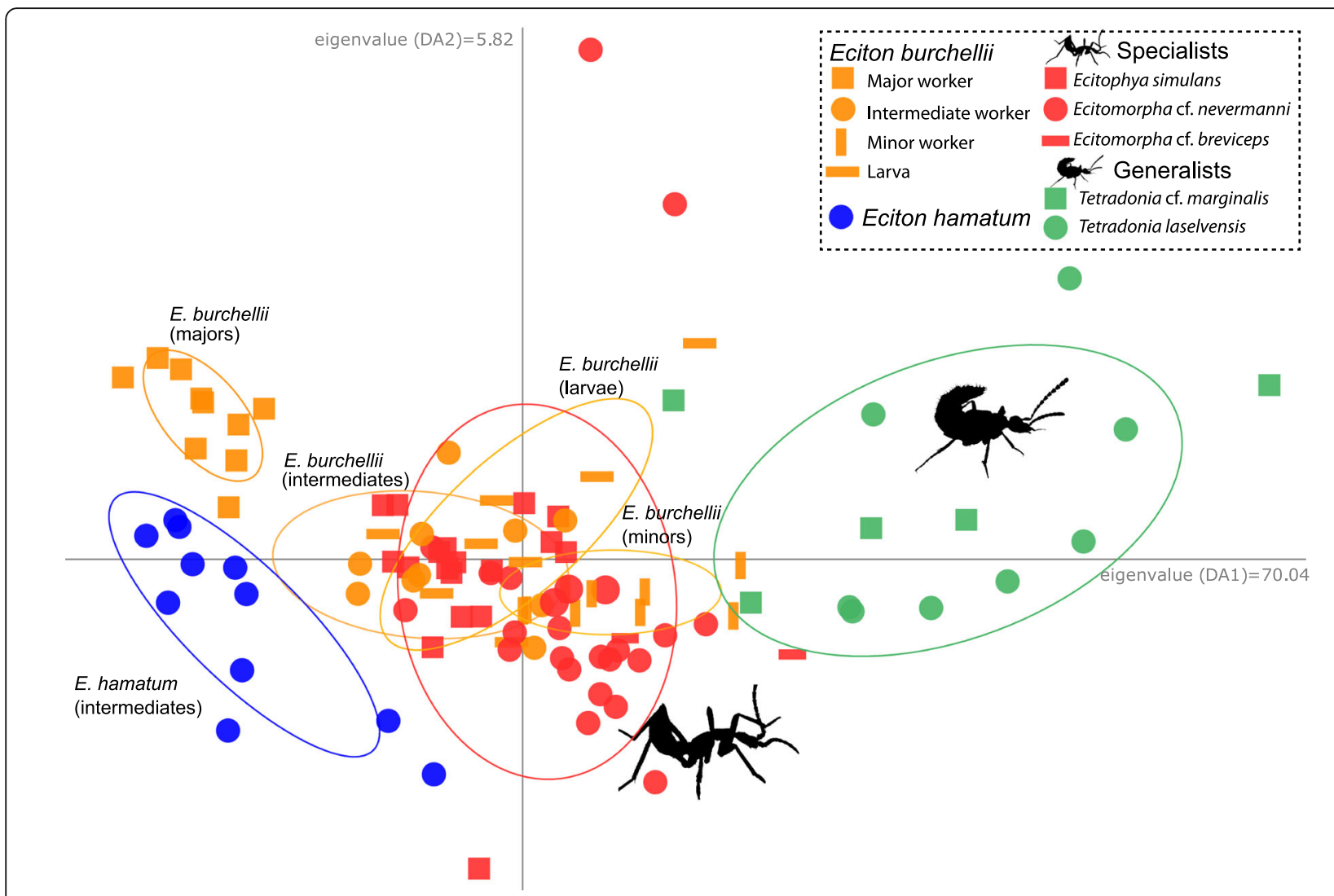

Fig. $4 \mathrm{CHC}$ profile similarity between ants and parasites. Discriminant analysis of principal components of $\mathrm{CHC}$ profiles for $E$. burchellii foreli (larvae $N=8$, minor workers $N=10$, intermediate workers $N=9$, major workers $N=10)$, E. hamatum intermediate workers $(N=11)$, beetle specialists $(N=45)$, and beetle generalists $(N=14)$. Eigenvalues are shown at the tip of axes. Ellipses depict $95 \%$ confidence intervals of different categories
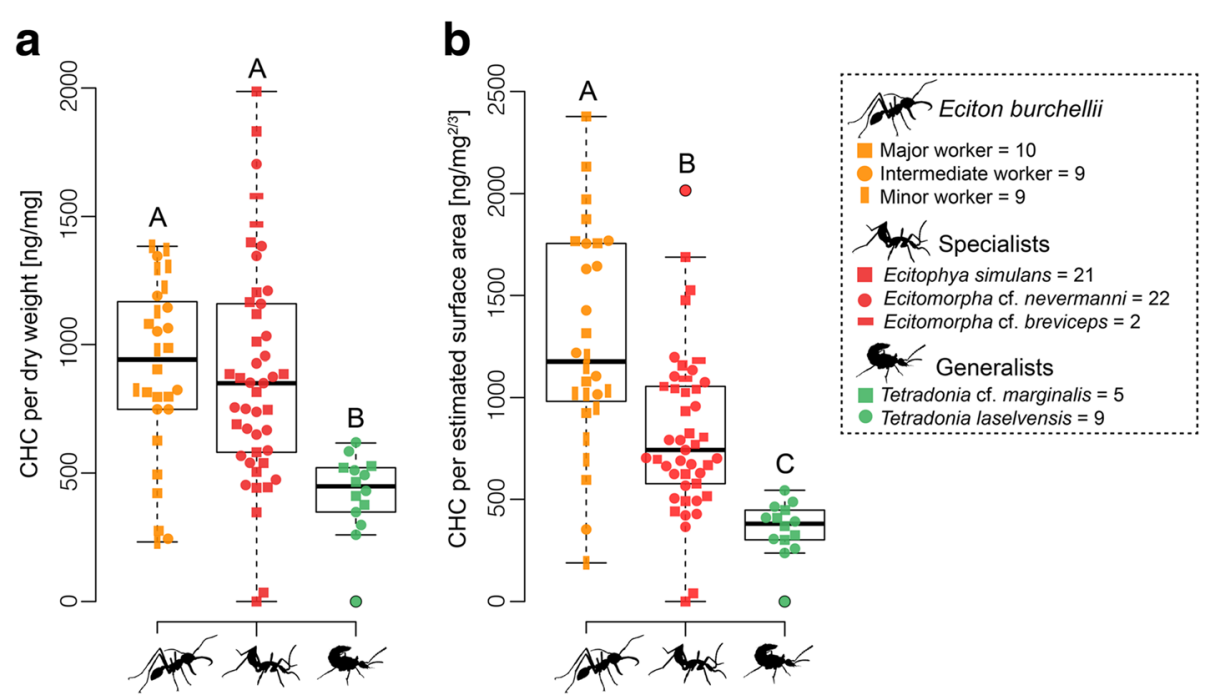

Fig. 5 Army ant and parasite CHC concentrations. CHC amount per dry weight (a) and CHC amount as a function of estimated surface area (b) plotted for Eciton burchellii foreli workers, beetle specialists, and beetle generalists. Sample sizes are given in the figure legend. Different letters depict significant differences $(p<0.05)$ as assessed by a Dunn's test 


\section{Resemblance to host CHC profiles - A comparison between specialists and generalists}

Almost 100 years after Wasmann hypothesized that antmimicking beetles resemble ants chemically [37] we can confirm his supposition (see also [84]). The close resemblance to host $\mathrm{CHC}$ profiles in Wasmannian mimics most likely constitutes a case of chemical mimicry (sensu [85]), which implies two things. First, Wasmannian mimics are detected by host ants as interesting entities, which is, for example, not the case in chemical crypsis (background matching) and chemical masquerade (matching of an uninteresting entity) (reviewed in [85]). Frequent interactions between hosts and Wasmannian mimics, including reciprocal antennation and grooming, demonstrated that ants perceived the guests as interesting entities. The first requirement to denote this association as mimetic is thus fulfilled, but we can only speculate about the second one: mimics need to benefit from a deception of the operator (here the host ants) $[85,86]$. Since $\mathrm{CHC}$ profiles in ants mediate nestmate recognition and the detection of alien species [38, 40, 87-90], mimicking those cues likely hampers the ants' recognition of mimics as heterospecific intruders. We consider it likely that ants mistake Wasmannian mimics as conspecific nestmates, a type of deception that has previously been suggested for various other ant-myrmecophile interactions $[9,18,19]$. However, to denote this resemblance as chemical mimicry requires evidence of host deception, for example, via manipulative experiments of the chemical cues as demonstrated in an army ant-associated silverfish [41]. Future studies should thus consider altering the $\mathrm{CHC}$ profiles of Wasmannian mimics experimentally to see whether the host behavior towards parasites is indeed influenced by the level of $\mathrm{CHC}$ similarity (e.g., $[41,58]$ ).

The same line of argument applies to beetle generalists. Compared to Wasmannian mimics, these generalists resembled the host's $\mathrm{CHC}$ profile less well and showed a higher profile variation and lower $\mathrm{CHC}$ concentrations, which might partly explain their lower level of social integration. Imperfect $\mathrm{CHC}$ mimicry in myrmecophileant systems is common, but the ultimate and proximate mechanisms behind a weak chemical host resemblance mostly remain speculative. Carrying only small quantities of CHCs compared to host ants has often been suggested to hamper recognition due to an inability of host ants to detect these cues (chemical insignificance sensu [19]; chemical hiding sensu [85]) (e.g., woodlice/ mites/phorid flies: [91]; syrphid flies: [92]; silverfish: [93]). On the contrary, the presence of only a few host $\mathrm{CHCs}$ in low quantities with slight compositional differences to the host has been suggested as a strategy of two parasitoid wasps to be detected by host ants [94]. In this case, the ants pick up the adult wasps and transport them out of the host nest, an essential step in the wasps' life cycle [94].

As we did not detect any aggression of host ants towards Tetradonia beetles in behavioral assays, we assume that even the weak similarity in $\mathrm{CHC}$ profiles to host ants is beneficial to avoid an immediate recognition, which generally triggers worker hostility. In contrast to many of the unspecialized myrmecophiles of red wood ants [17], for example, the CHC profiles of Tetradonia beetles still resembled the $\mathrm{CHC}$ profiles of host ants fairly well in that they carried the exact same $\mathrm{CHCs}$ as host ants without possessing any idiosyncratic CHCs. The latter phenomenon is common among social insect symbionts (e.g., beetles: [95, 96]; eucharitid wasps: [94, 97]; silverfish: [41, 98]; spiders: [58, 98, 99]; syrphid flies: [92, 100]), most likely because a symbiont possessing components absent in the host cuticular profile would facilitate being recognized as an intruder. A very similar pattern to Tetradonia's chemical resemblance - same $\mathrm{CHCs}$ as host ants in non-integrated species - was previously detected in staphylinid parasites of SoutheastAsian Leptogenys army ants $[59,91]$. We speculate that host profile similarity in non-integrated generalists might arise as a by-product of ant predation by physical $\mathrm{CHC}$ transfer from host ants to predatory beetles (see also discussion in [101]). This might represent one of the first steps during the evolution of myrmecophily to lower defensive responses by ant hosts (see also [17]).

\section{Origin of mimetic $\mathrm{CHCs}$}

There are two principal mechanisms for how myrmecophiles can obtain mimetic $\mathrm{CHCs}$, and these mechanisms differently affect host-symbiont co-evolutionary dynamics $[9,85]$. Myrmecophiles can either acquire mimetic $\mathrm{CHCs}$ from host workers via physical contact (acquired chemical mimicry sensu [85]), they can synthesize mimetic cues themselves (innate chemical mimicry sensu [85]), or use a combination of both strategies (reviewed in $[9,18,19])$. Acquired chemical mimicry seems to be the most common strategy among myrmecophiles [19], and we consider it likely that this is the primary mechanism in Wasmannian mimics and Tetradonia beetles. Wasmannian mimics engaged in intensive and constant host contact (see also [24]), which likely transferred host $\mathrm{CHCs}$ to the beetles as demonstrated in another army ant-parasite system [41, 58]. Tetradonia beetles are predators of Eciton ants [24, 26] and we assume that they acquired host $\mathrm{CHCs}$ during the handling and feeding process. This weaker match to host profiles combined with their lower contact frequency with host ants suggests that constantly updating mimetic $\mathrm{CHCs}$ via host contact is necessary to establish and maintain a good match to host $\mathrm{CHC}$ profiles (see also $[28,41,58])$. 
Besides $\mathrm{CHC}$ acquisition, an additional de novo synthesis of certain key compounds is likewise possible [18, 19, 96]. Experimental designs to test for de novo synthesis of mimetic cues include $\mathrm{CHC}$ extractions of myrmecophiles without previous host contact [102-104] and $\mathrm{CHC}$ extractions of myrmecophiles that were experimentally separated from host ants for an extended period of time [28, 41, 58, 93]. These experiments could be done with Tetradonia beetles, but carrying them out with Wasmannian mimics is difficult for two reasons. First, all adults have been collected from host colonies and immatures have not been found yet, so $\mathrm{CHC}$ profiles of individuals without previous host contact cannot be studied. Second, separating the beetles from host ants is impossible as they die after a few days of isolation ([24, 32], and personal observation). At this point, it remains uncertain whether innate chemical mimicry plays a role for deceiving host ants in Wasmannian mimics and Tetradonia beetles - a mechanism that might be particularly important during the initial contact with army ant colonies (e.g., [102, 105-107]).

\section{$\mathrm{CHC}$ concentration}

Besides compositional differences in $\mathrm{CHC}$ profiles, $\mathrm{CHC}$ concentrations might also play a role in chemical communication of ants (e.g., [108]) and in chemical mimicry of myrmecophiles [17, 41, 58]. At this point, this is highly speculative, but it points the way to further research. As expected, well-integrated specialists had higher concentrations of mimetic $\mathrm{CHCs}$ compared to non-integrated generalists. The $\mathrm{CHC}$ concentration, i.e. the $\mathrm{CHC}$ amount per surface area or body mass, has hitherto largely been neglected as a factor for chemical integration of myrmecophiles [41, 58, 91, 95, 109]. Maybe this is because it is difficult to measure an animal's surface area. Previous studies estimated myrmecophile surface areas using approximations of geometrical shapes $[17,41,58,109]$. While these simplified calculations allowed to standardize an animal's $\mathrm{CHC}$ amount for vastly different body sizes, such calculations can only be treated as rough estimates of an animal's actual surface area [109]. In the present study, we used an animal's dry weight as estimator for body size. The dry weight, and in particular the dry weight ${ }^{2 / 3}$, is generally a good predictor of an insect's surface area [76, 77]. Ideally, future studies will assess surface areas via 3-D scans directly to calculate $\mathrm{CHC}$ concentrations of ants and their mimics $[76,77]$, but we suggest the dry weight as a reliable and feasibly measurable surrogate. Using dry weight as surface area predictor might be useful in studying both, the role of $\mathrm{CHC}$ concentration in ant nestmate recognition (e.g., [108]) and in the recognition of chemical mimics (e.g., [41]).

\section{Additional adaptations to myrmecophily}

It is important to mention that integration mechanisms of myrmecophiles are multifaceted. Chemical mimicry of host $\mathrm{CHCs}$ is one among many possible mechanisms to cope with ants, also including morphological and behavioral adaptations [2, 3, 24, 31, 110], acoustical mimicry $[29,30,111]$, and attractive or defensive chemical gland secretions [112-115]. It is the interplay between these factors that ultimately governs host-myrmecophile interactions. We assume that the host resemblance in anatomy and behavior, as found in Wasmannian mimics and various other myrmecophile taxa [2, 3, 8, 116-118], supplements chemical mimicry in deceiving host ants, so that ants mistake intruders for nestmates. More than 100 years after Wasmann's tactile mimicry hypothesis, the importance of tactile cues in ant nestmate recognition and in tactile mimicry of myrmecophiles is still largely unexplored. Anatomical and chemical mimicry of host ants in a variety of unrelated myrmecophiles (e.g., $[3,8,18,31])$ suggests that the ants' tactile and odor inspection via the antennae is a prime selective agent driving some of the most integrated myrmecophiles to mimic both, host body shape and host $\mathrm{CHC}$ profile (see also discussion in [4]).

\section{Specialization - host specificity trade-off}

The evolution of host-specialization in parasites and parasitoids is considered to be a trade-off [10]. Specialization on a single host species is supposed to increase a parasite's fitness on that particular host, but it comes at the cost of a high dependency on a single host species [10]. For example, a recent community study of host specificity in phorid parasitoids infecting leaf-cutter ants revealed high degrees of host specificity with 13 out of 20 species exploiting only a single host species [13]. We have compared the level of specialization in terms of social and chemical integration between army antassociated beetle specialists and beetle generalists. Our results support the hypothesis that the evolution of host-specialization in parasites is a trade-off between the range of potential host species and the level of specialization (see also [92]). However, the present study only focused on two beetle groups, and species within the groups were phylogenetically closely related. To test whether this pattern universally holds for ant-parasite communities, future studies need to include a greater diversity of species including phylogenetically more distantly-related parasites.

\section{Additional files}

Additional file 1: Table S1. Colony collection data (downloadable on the journal's webpage; not included here). (XLSX 13 kb) 
Additional file 2: Table S2. Specimen and collection information including GenBank accession numbers (downloadable on the journal's webpage; not included here). (XLSX $36 \mathrm{~kb}$ )

Additional file 3: Figure S1. Assessment of species boundaries in Eciton-associated Wasmannian mimics via nuclear loci. Figure S2. Dry weight measurements of ants and parasites. Figure S3. Relationship of dry weight and CHC amount. Figure S4. Distribution of pairwise p-distances. Figure S5. Morphological distinction of studied Ecitomorpha species. Table S3. Re-assignment of samples to groups using a DAPC analysis. (PDF $4155 \mathrm{~kb}$ )

Additional file 4: Interactions between Wasmannian mimics and army ant host workers. Video credit: Philipp O. Hönle. (MP4 34 mb)

\section{Acknowledgements}

We thank two anonymous reviewers for valuable comments, Sebastian Schmelzle for help with graphical representation, Sebastian Kruse for help with GCMS and dry weight analyses, and Sebastian Pohl for help during field work. We thank Adrian Pinto, Carlos de la Rosa, Bernal Matarrita Carranza, Ronald Vargas and Danilo Brenes Madrigal, as well as the entire staff of La Selva Biological Station for their generous support throughout the project. CvB was supported by the German Science Foundation (BE 5177/1-1 and BE 5177/3-1), the National Geographic Society's Committee for Research and Exploration (9393-13) and a Bristol-Myers Squibb Postdoctoral Fellowship from The Rockefeller University. DJCK was supported by a Carl \& Marian Rettenmeyer Ant-Guest Endowment Award. AB was supported by the German National Academic Foundation (Studienstiftung des deutschen Volkes).

\section{Availability of data and materials}

The datasets supporting the conclusions of this article are included within the article and its additional files, and are deposited at GenBank and BOLD. Voucher specimens are deposited in museum collections.

\section{Authors' contributions}

CVB and DJCK designed the study. CVB, GB and DJCK carried out the field work. CVB, AB, MM and DJCK wrote the manuscript. CvB, GB and DJCK carried out genetic analyses. CVB, AB and JW carried out chemical analyses. CvB carried out behavioural assays and took specimen images. CVB and MM identified species and provided morphological descriptions. CVB and JW measured specimen dry weights. CVB, AB and DJCK carried out statistical analyses. DJCK supervised the project. All authors read and approved the final manuscript.

\section{Ethics approval and consent to participate}

The present study complies with institutional, national, and international ethical guidelines. Research and specimen export permits for Costa Rica were issued by the 'Ministry of the Environment, Energy and Technology' (MINAET; permit numbers: 192-2012-SINAC and R-009-2014-OT-CONAGEBIO).

\section{Competing interests}

The authors declare that they have no competing interests.

\section{Publisher's Note}

Springer Nature remains neutral with regard to jurisdictional claims in published maps and institutional affiliations.

\section{Author details}

${ }^{1}$ Ecological Networks, Department of Biology, Technische Universität Darmstadt, 64287 Darmstadt, Germany. ${ }^{2}$ Laboratory of Social Evolution and Behavior, The Rockefeller University, New York, NY 10065, USA. ${ }^{3}$ The Kyushu University Museum, Hakozaki 6-10-1, Fukuoka 812-8581, Japan. ${ }^{4}$ Bard College, Annandale-on-Hudson, NY 12504, USA.

Received: 26 September 2017 Accepted: 16 January 2018

Published online: 16 March 2018

\section{References}

1. Wasmann E. Kritisches Verzeichniss der myrmekophilen und termitophilen Arthropoden. Mit Angabe der Lebensweise und mit Beschreibung neuer Arten. Berlin: Felix L. Dames; 1894.
2. Hölldobler B, Wilson EO. The ants. Cambridge, MA: Harvard University Press; 1990

3. Kistner $\mathrm{DH}$. Social and evolutionary significance of social insect symbionts. In: Hermann HR, editor. Social insects. New York, NY: Academic Press; 1979. p. 339-413.

4. Parker J. Myrmecophily in beetles (Coleoptera): evolutionary patterns and biological mechanisms. Myrmecol News. 2016;22:65-108.

5. Rettenmeyer CW, Rettenmeyer ME, Joseph J, Berghoff SM. The largest animal association centered on one species: the army ant Eciton burchellii and its more than 300 associates. Insect Soc. 2011;58:281-92.

6. Parker J, Grimaldi DA. Specialized myrmecophily at the ecological dawn of modern ants. Curr Biol. 2014;24:2428-34.

7. Thomas JA, Schönrogge K, Elmes GW. Specializations and host associations of social parasites of ants. In: Fellowes MDE, Holloway GJ, Rolff J, editors. Insect evolutionary ecology. Reading: Proceedings of the Royal Entomological Society's 22nd symposium: CABI; 2005. p. 475-514.

8. Kistner DH. The social insects' bestiary. In: Hermann HR, editor. Social insects. New York, NY: Academic Press; 1982. p. 1-244.

9. Nash DR, Boomsma JJ. Communication between hosts and social parasites. In: D'Ettorre P, Hughes DP, editors. Sociobiology of communication: an interdisciplinary approach. New York, NY: Oxford University Press; 2008. p. 55-79.

10. Schmid-Hempel P. Evolutionary parasitology: the integrated study of infections, immunology, ecology, and genetics. New York, NY: Oxford University Press; 2011.

11. Ivens ABF, von Beeren C, Blüthgen N, Kronauer DJC. Studying the complex communities of ants and their symbionts using ecological network analysis. Annu Rev Entomol. 2016:61:353-71.

12. Witek M, Barbero F, Markó B. Myrmica ants host highly diverse parasitic communities: from social parasites to microbes. Insect Soc. 2014:61:307-23.

13. Elizalde $L$, Patrock $R$, Disney $R$, Folgrant $P$. Spatial and temporal variation in host-parasitoid interactions: leafcutter ant hosts and their phorid parasitoids. Ecol Entomol. 2017; https://doi.org/10.1111/een.12477.

14. Müller CB, Adriaanse ICT, Belshaw R, Godfray HCJ. The structure of an aphidparasitoid community. J Anim Ecol. 1999;68:346-70.

15. Parmentier T, Dekoninck W, Wenseleers T. A highly diverse microcosm in a hostile world: a review on the associates of red wood ants (Formica rufa group). Insect Soc. 2014;61:229-37.

16. Parmentier T, Dekoninck W, Wenseleers T. Do well-integrated species of an inquiline community have a lower brood predation tendency? A test using red wood ant myrmecophiles. BMC Evol Biol. 2016;16:12.

17. Parmentier T, Dekoninck W, Wenseleers T. Arthropods associate with their red wood ant host without matching nestmate recognition cues. J Chem Ecol. 2017:43:644-61.

18. Akino T. Chemical strategies to deal with ants: a review of mimicry, camouflage, propaganda, and phytomimesis by ants (Hymenoptera: Formicidae) and other arthropods. Myrmecol News. 2008;11:173-81.

19. Lenoir A, d'Ettorre P, Errard C, Hefetz A. Chemical ecology and social parasitism in ants. Annu Rev Entomol. 2001:46:573-99.

20. von Beeren C, Maruyama M, Kronauer DJC. Community sampling and integrative taxonomy reveal new species and host specificity in the army ant-associated beetle genus Tetradonia (Coleoptera, Staphylinidae, Aleocharinae). PLoS One. 2016:11:e0165056.

21. von Beeren C, Maruyama M, Kronauer DJC. Cryptic diversity, high host specificity and reproductive synchronization in army ant-associated Vatesus beetles. Mol Ecol. 2016;25:990-1005.

22. Tishechkin AK, Kronauer DJC, von Beeren C. Taxonomic review and natural history notes of the army ant-associated beetle genus Ecclisister Reichensperger (Coleoptera: Histeridae: Haeterinae). Coleopt Bull. 2017;71: 279-88.

23. von Beeren C, Tishechkin AK. Nymphister kronaueri von Beeren \& Tishechkin sp. nov., an army ant-associated beetle species (Coleoptera: Histeridae: Haeteriinae) with an exceptional mechanism of phoresy. BMC Zool. 2017:2:3.

24. Akre RD, Rettenmeyer CW. Behavior of Staphylinidae associated with army ants (Formicidae: Ecitonini). J Kansas Entomol Soc. 1966:39:745-82.

25. Maruyama M, Parker J. Deep-time convergence in rove beetle symbionts of army ants. Curr Biol. 2017:27:920-6.

26. Jacobson HR, Kistner DH. A redescription of the myrmecophilous genus Tetradonia and a description of a new, closely related, free living genus Tetradonella (Coleoptera: Staphylinidae). Sociobiology. 1998;31:151-279. 
27. Seevers $\mathrm{CH}$. The systematics, evolution and zoogeography of staphylinid beetles, associated with army ants (Coleoptera, Staphylinidae). Fieldiana Zool. 1965;47:137-351.

28. Vander Meer RK, Wojcik DP. Chemical mimicry in the myrmecophilous beetle Myrmecaphodius excavaticollis. Science. 1982;218:806-8.

29. Di Giulio A, Maurizi E, Barbero F, Sala M, Fattorini S, Balletto E, et al. The pied piper: a parasitic beetle's melodies modulate ant behaviours. PLoS One. 2015;10:e0130541.

30. Barbero F, Thomas JA, Bonelli S, Balletto E, Schönrogge K. Queen ants make distinctive sounds that are mimicked by a butterfly social parasite. Science. 2009:323:782-5

31. Gotwald WH Jr. Army ants: the biology of social predation. Comstock Pub. Associates: Ithaca, NY; 1995.

32. Kistner DH, Jacobson HR. Cladistic analysis and taxonomic revision of the ecitophilous tribe Ecitocharini with studies of their behavior and evolution (Coleoptera, Staphylinidae, Aleocharinae). Sociobiology. 1990;17:333-480.

33. Pérez-Espona S, Goodall-Copestake WP, Berghoff SM, Edwards KJ, Franks NR. Army imposters: diversification of army ant-mimicking beetles with their Eciton hosts. Insect Soc. 2017; https://doi.org/10.1007/s00040-017-0588-1:1-17.

34. Rettenmeyer CW. Insect mimicry. Annu Rev Entomol. 1970;15:43-74.

35. Schneirla TC. Army ants: a study in social organization. Topoff HR, editor. San Francisco, CA: W. H. Freeman \& Co.; 1971.

36. Bulova S, Purce K, Khodak P, Sulger E, O'Donnell S. Into the black and back: the ecology of brain investment in Neotropical army ants (Formicidae: Dorylinae). Sci Nat. 2016;103:31.

37. Wasmann E, Aachen S. Die Ameisenmimikry. Naturwissenschaften. 1925;13: 944-51.

38. Hefetz A. The evolution of hydrocarbon pheromone parsimony in ants (Hymenoptera: Formicidae) - interplay of colony odor uniformity and odor idiosyncrasy. A review Myrmecol News. 2007;10:59-68.

39. Blomquist GJ, Bagnères A-G. Insect hydrocarbons: biology, biochemistry, and chemical ecology. Cambridge: Cambridge University Press; 2010.

40. Leonhardt SD, Menzel F, Nehring V, Schmitt T. Ecology and evolution of communication in social insects. Cell. 2016;164:1277-87.

41. von Beeren C, Schulz S, Hashim R, Witte V. Acquisition of chemical recognition cues facilitates integration into ant societies. BMC Ecol. 2011;11:30.

42. Mayr G. Ueber Eciton-Labidus Wien Entomol Ztg. 1886;5:115-22.

43. Fabricius JC. Species insectorum, exhibentes eorum differentias specificas, synonyma auctorum, loca natalia, metamorphosin, adjectis observationibus, descriptionibus. Hamburgi et Kilonii,impensis CE Bohnii; 1781.

44. Roger J. Die neu aufgeführten Gattungen und Arten meines FormicidenVerzeichnisses nebst Ergänzung einiger früher gegebenen Beschreibungen. Berl Entomol Zeit. 1863;7:131-214.

45. Borgmeier T. Die Wanderameisen der Neotropischen Region (Hym. Formicidae): Eine taxonomisch-biologische Studie nebst Bemerkungen ueber Grundfragen der Systematik. Stud Entomol. 1955;3:1-716.

46. Weber NA. A new Panama Eciton (Hymenoptera, Formicidae). Am Mus Novit. 1949:1441:1-8.

47. Reichensperger A. Beitrag zur Kenntnis der Myrmekophilenfauna Brasiliens und Costa Ricas III.(Col. Staphyl. Hist.). Arb morph taxon Ent Berlin-Dahlem. 1935;2:188-218.

48. Reichensperger A. Neue Beiträge zur Artenkenntnis und zur Lebensweise myrmekophiler Histeriden. Verh d III Int Entomol Kongr (Zürich). 1926;2:184-203.

49. Watkins JF II. The army ants of Mexico (Hymenoptera: Formicidae: Ecitoninae). J Kansas Entomol Soc. 1982;55:197-247.

50. Watkins JF II. The identification and distribution of new world army ants (Dorylinae: Formicidae). Waco, TX: The Markham Press Fund of Baylor University Press; 1976.

51. Longino J. Ants of Costa Rica. http://ants.biology.utah.edu/ longino/ AntsofCostaRica.html. 2010

52. Folmer O, Black M, Hoeh W, Lutz R, Vrijenhoek R. DNA primers for amplification of mitochondrial cytochrome c oxidase subunit I from diverse metazoan invertebrates. Mol Marine Biol Biotechnol. 1994:3:294-9.

53. von Beeren C, Stoeckle MY, Xia J, Burke G, Kronauer DJC. Interbreeding among deeply divergent mitochondrial lineages in the American cockroach (Periplaneta americana). Sci Rep. 2015;5:8297.

54. Kearse M, Moir R, Wilson A, Stones-Havas S, Cheung M, Sturrock, S, Buxton, S, et al. Geneious Basic: An integrated and extendable desktop software platform for the organization and analysis of sequence data. Bioinformatics. 2012;28:1647-9
55. Parker M, Stones-Havas S, Starger C, Meyer C. Laboratory information management systems for DNA barcoding. In: Kress WJ, Erickson DL, editors. DNA barcodes: methods and protocols. Methods in molecular biology, vol. 858; 2012. p. 269-310.

56. Tamura K, Stecher G, Peterson D, Filipski A, Kumar S. Molecular evolutionary genetics analysis version 6.0. Mol Biol Evol. 2013;30:2725-9.

57. Franks NR. Reproduction, foraging efficiency and worker polymorphism in army ants. In: Hölldobler B, Lindauer M, editors. Experimental Behavioural ecology and sociobiology. Fortschritte der Zoologie. Stuttgart, New York: G Fischer Verlag; 1985. p. 91-107.

58. von Beeren $\mathrm{C}$, Hashim R, Witte V. The social integration of a myrmecophilous spider does not depend exclusively on chemical mimicry. J Chem Ecol. 2012:38:262-71.

59. von Beeren C, Maruyama M, Hashim R, Witte V. Differential host defense against multiple parasites in ants. Evol Ecol. 2011;25:259-76.

60. Team RDC. R: a language and environment for statistical computing $R$ Foundation for Statistical Computing, 2.13. Vienna; 2011. isbn:ISBN 3900051-07-0. URL http://www. R-project. org

61. Kruskal WH, Wallis WA. Use of ranks in one-criterion variance analysis. J Am Stat Assoc. 1952;47:583-621.

62. Dunn OJ. Multiple comparisons using rank sums. Technometrics. 1964;6:241-52.

63. Benjamini Y, Hochberg Y. Controlling the false discovery rate: a practical and powerful approach to multiple testing. J R Statist Soc B. 1995;57:289-300.

64. Pohlert T. The pairwise multiple comparison of mean ranks package (PMCMR). R package. 2014; http://CRAN.R-project.org/package=PMCMR.

65. Van den Dool H, Kratz PD. A generalization of the retention index system including linear temperature programmed gas-liquid partition chromatography. J Chromatogr A. 1963;11:463-71.

66. Carlson DA, Bernier UR, Sutton BD. Elution patterns from capillary GC for methyl-branched alkanes. J Chem Ecol. 1998;24:1845-65.

67. Schulz S. Composition of the silk lipids of the spider Nephila clavipes. Lipids. 2001;36:637-47.

68. Dunkelblum E, Tan SH, Silk PJ. Double-bond location in monounsaturated fatty acids by dimethyl disulfide derivatization and mass spectrometry: application to analysis of fatty acids in pheromone glands of four Lepidoptera. J Chem Ecol. 1985;11:265-77.

69. Brückner A, Heethoff M. A chemo-ecologists' practical guide to compositional data analysis. Chemoecology. 2017;27:33-46.

70. Lachenbruch PA, Goldstein M. Discriminant analysis. Biometrics. 1979;35:69-85.

71. Anderson MJ. Permutational multivariate analysis of variance volume 26. Auckland: Department of Statistics, University of Auckland; 2005. p. 32-46.

72. Bray JR, Curtis JT. An ordination of the upland forest communities of southern Wisconsin. Ecol Monogr. 1957;27:325-49.

73. Jombart T. Adegenet: a R package for the multivariate analysis of genetic markers. Bioinformatics. 2008;24:1403-5.

74. Oksanen J, Kindt R, Legendre P, O'Hara B, Stevens MHH, Oksanen MJ, et al. The vegan package. Community ecology package. 2007;10:631-7.

75. Anderson M, Gorley RN, Clarke RK. Permanova+ for primer: guide to software and statistical methods. Primer-E: Plymouth; 2008.

76. Brückner $A$, Heethoff $M$, Blüthgen $N$. The relationship between epicuticular long-chained hydrocarbons and surface area-volume ratios in insects (Diptera, Hymenoptera, Lepidoptera). PLoS One. 2017;12:e0175001.

77. Kühsel S, Brückner A, Schmelzle S, Heethoff M, Blüthgen N. Surface areavolume ratios in insects. Insect Sci. 2017;24:829-41.

78. Galilei G. Discorsi e dimostrazioni matematiche intorno à due nuove scienze attenenti alla mecanica \& i movimenti locali. Leida: Elsevier; 1638.

79. Crozier RH, Dix MW. Analysis of two genetic models for the innate components of colony odor in social hymenoptera. Behav Ecol Sociobiol. 1979:4:217-24.

80. Reichensperger A. Ecitophilen aus Costa Rica (II), Brasilien und Peru (staph Hist. Clavig.). Rev Entomol. 1933;3:179-94.

81. Stadler B, Dixon T. Mutualism: ants and their insect partners. Cambridge: Cambridge University Press; 2008.

82. Blüthgen N, Menzel F, Hovestadt T, Fiala B, Blüthgen N. Specialization, constraints, and conflicting interests in mutualistic networks. Curr Biol. 2007;17:341-6.

83. Rettenmeyer CW. Arthropods associated with Neotropical army ants with a review of the behavior of these ants (Arthropoda; Formicidae: Dorylinae). PhD thesis. University of Kansas; 1961. 
84. Maruyama M, Akino T, Hashim R, Komatsu T. Behavior and cuticular Hydrocarbons of myrmecophilous insects (Coleoptera: Staphylinidae; Diptera: Phoridae; Thysanura) associated with asian Aenictus army ants (Hymenoptera; Formicidae). Sociobiology. 2009;54:19-35.

85. von Beeren C, Pohl S, Witte V. On the use of adaptive resemblance terms in chemical ecology. Psyche. 2012;2012:635761.

86. Dettner K, Liepert C. Chemical mimicry and camouflage. Annu Rev Entomol. 1994;39:129-54.

87. van Zweden JS, d'Ettorre P. Nestmate recognition in social insects and the role of hydrocarbons. In: Blomquist GJ, Bagnères A-G, editors. Insect hydrocarbons: biology, biochemistry and chemical ecology. Cambridge: Cambridge University Press; 2010. p. 222-43.

88. Sharma KR, Enzmann BL, Schmidt Y, Moore D, Jones GR, Parker J, et al Cuticular hydrocarbon pheromones for social behavior and their coding in the ant antenna. Cell Rep. 2015:12:1261-71.

89. Sturgis SJ, Gordon DM. Nestmate recognition in ants (Hymenoptera: Formicidae): a review. Myrmecol News. 2012;16:101-10.

90. Witte V, Schliessmann D, Hashim R. Attack or call for help? Rapid individual decisions in a group-hunting ant. Behav Ecol. 2010;21:1040-7.

91. Witte V, Leingärtner A, Sabaß L, Hashim R, Foitzik S. Symbiont microcosm in an ant society and the diversity of interspecific interactions. Anim Behav. 2008;76:1477-86

92. Witek M, Casacci LP, Barbero F, Patricelli D, Sala M, Bossi S, et al. Interspecific relationships in co-occurring populations of social parasites and their host ants. Biol J Linn Soc Lond. 2013;109:699-709.

93. Lenoir A, Chalon Q, Carvajal A, Ruel C, Barroso Á, Lackner T, et al. Chemical integration of myrmecophilous guests in Aphaenogaster ant nests. Psyche. 2012;2012:840860

94. Pérez-Lachaud G, Bartolo-Reyes JC, Quiroa-Montalván CM, Cruz-López L, Lenoir A, Lachaud J-P. How to escape from the host nest: imperfect chemical mimicry in eucharitid parasitoids and exploitation of the ants' hygienic behavior. J Insect Physiol. 2015;75:63-72.

95. Lenoir A, Háva J, Hefetz A, Dahbi A, Cerdá X, Boulay R. Chemical integration of Thorictus myrmecophilous beetles into Cataglyphis ant nests. Biochem Syst Ecol. 2013;51:335-42.

96. Howard RW, McDaniel CA, Blomquist GJ. Chemical mimicry as an integrating mechanism: cuticular hydrocarbons of a termitophile and its host. Science. 1980:210:431-3.

97. Vander Meer RK, Jouvenaz DP, Wojcik DP. Chemical mimicry in a parasitoid (Hymenoptera: Eucharitidae) of fire ants (Hymenoptera: Formicidae). J Chem Ecol. 1989;15:2247-61.

98. Witte V, Foitzik S, Hashim R, Maschwitz U, Schulz S. Fine tuning of social integration by two myrmecophiles of the ponerine army ant Leptogenys distinguenda. J Chem Ecol. 2009;35:355-67.

99. Allan RA, Capon RJ, Brown W, Elgar MA. Mimicry of host cuticular hydrocarbons by salticid spider Cosmophasis bitaeniata that preys on larvae of tree ants Oecophylla smaragdina. J Chem Ecol. 2002;28:835-48.

100. Howard RW, Akre RD, Garnett WB. Chemical mimicry in an obligate predator of carpenter ants (Hymenoptera: Formicidae). Ann Entomol Soc Am. 1990;83:607-16.

101. Elgar MA, Allan RA. Predatory spider mimics acquire colony-specific cuticular hydrocarbons from their ant model prey. Naturwissenschaften. 2004:91:143-7.

102. Akino T, Knapp JJ, Thomas JA, Elmes GW. Chemical mimicry and host specificity in the butterfly Maculinea rebeli, a social parasite of Myrmica ant colonies. Proc R Soc Lond B. 1999;266:1419-26.

103. Elmes GW, Akino T, Thomas JA, Clarke RT, Knapp JJ. Interspecific differences in cuticular hydrocarbon profiles of Myrmica ants are sufficiently consistent to explain host specificity by Maculinea (large blue) butterflies. Oecologia. 2002;130:525-35.

104. Schlick-Steiner BC, Steiner FM, Höttinger H, Nikiforov A, Mistrik R, Schafellner

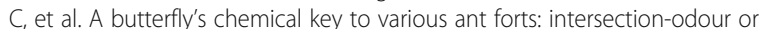
aggregate-odour multi-host mimicry? Naturwissenschaften. 2004;91:209-14.

105. Als TD, Nash DR, Boomsma JJ. Adoption of parasitic Maculinea alcon caterpillars (Lepidoptera: Lycaenidae) by three Myrmica ant species. Anim Behav. 2001;62:99-106

106. Solazzo G, Moritz RFA, Settele J. Choice behaviour of Myrmica rubra workers between ant larvae and larvae of their Phengaris (Maculinea) nausithous nest parasites. Insect Soc. 2013;60:57-64.

107. Nash DR, Als TD, Maile R, Jones GR, Boomsma JJ. A mosaic of chemical coevolution in a large blue butterfly. Science. 2008;319:88-90.
108. Ichinose K, Lenoir A. Ontogeny of hydrocarbon profiles in the ant Aphaenogaster senilis and effects of social isolation. C R Biol. 2009;332:697-703.

109. Nehring V, Dani FR, Calamai L, Turillazzi S, Bohn H, Klass K-D, et al. Chemical disguise of myrmecophilous cockroaches and its implications for understanding nestmate recognition mechanisms in leaf-cutting ants. BMC Ecol. 2016;16:35.

110. Maruyama M, Disney RHL, Hashim R. Three new species of legless, wingless scuttle flies (Diptera: Phoridae) associated with army ants (Hymenoptera: Formicidae) in Malaysia. Sociobiology. 2008;52:485-96.

111. Thomas JA, Schönrogge K, Bonelli S, Barbero F, Balletto E. Corruption of ant acoustical signals by mimetic social parasites: Maculinea butterflies achieve elevated status in host societies by mimicking the acoustics of queen ants. Commun Integr Biol. 2010;3:169-71.

112. Hölldobler B. Zur Physiologie der Gast-Wirt-Beziehungen (Myrmecophilie) bei Ameisen. II. Das Gastverhältnis des imaginalen Atemeles pubicollis Bris. (Col. Staphylinidae) zu Myrmica und Formica (Hym. Formicidae). Z vergl Physiologie. 1970;66:215-50.

113. Stoeffler M, Tolasch T, Steidle JLM. Three beetles—three concepts. Different defensive strategies of congeneric myrmecophilous beetles. Behav Ecol Sociobiol. 2011;65:1605-13.

114. Stoeffler M, Maier TS, Tolasch T, Steidle JLM. Foreign-language skills in rovebeetles? Evidence for chemical mimicry of ant alarm pheromones in myrmecophilous Pella beetles (Coleoptera: Staphylinidae). J Chem Ecol. 2007;33:1382-92.

115. Hojo MK, Pierce NE, Tsuji K. Lycaenid caterpillar secretions manipulate attendant ant behavior. Curr Biol. 2015:25:2260-4.

116. Cushing PE. Spider-ant associations: an updated review of myrmecomorphy, myrmecophily, and myrmecophagy in spiders. Psyche. 2012;2012:151989.

117. Komatsu T, Maruyama M, Itino T. Behavioral differences between two ant cricket species in Nansei Islands: host-specialist versus host-generalist. Insect Soc. 2009;56:389-96.

118. Henderson G, Akre RD. Biology of the myrmecophilous cricket, Myrmecophila manni (Orthoptera: Gryllidae). J Kansas Entomol Soc. 1986:59:454-67.

\section{Submit your next manuscript to BioMed Central and we will help you at every step:}

- We accept pre-submission inquiries

- Our selector tool helps you to find the most relevant journal

- We provide round the clock customer support

- Convenient online submission

- Thorough peer review

- Inclusion in PubMed and all major indexing services

- Maximum visibility for your research

Submit your manuscript at www.biomedcentral.com/submit
) Biomed Central 